\title{
An Evaluation of Best Practices in an Air Quality Student Science Project in Ethiopia
}

\author{
Johannes Dirk Dingemanse ${ }^{1 *}$ (), Geertje Dingemanse-de Wit ${ }^{2}$ (])
}

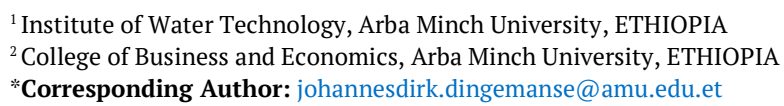

Citation: Dingemanse, J. D., \& Dingemanse-de Wit, G. (2022). An Evaluation of Best Practices in an Air Quality Student Science Project in Ethiopia. Aquademia, 6(1), ep22001. https://doi.org/10.21601/aquademia/11828

ARTICLE INFO

Received: 7 Jan. 2022

Accepted: 27 Feb. 2022

\begin{abstract}
A science project as part of a student's curriculum, which we call student science, might be the answer to two problems for a low-income country like Ethiopia: conventional science can be expensive and many students lack training in practical skills. Earlier studies have been conducted with respect to lay people (citizens or students) conducting (parts of) research (e.g. citizen science), but rarely in the context of a public university in a lowincome country. A student science project at Arba Minch University (Ethiopia) has been evaluated in three steps. Firstly, best practices for student science projects are derived from the literature. Secondly, it is evaluated to what extent these best practices were executed in an air quality student science project executed by 33 groups of undergraduate students at Arba Minch University. Thirdly, the scientific contribution of the project is evaluated by assessing the quality of the data in comparison to studies in similar scenarios, as well as its relation to a knowledge gap and a problem for the community. We find that the best practices from earlier studies are feasible in the study context. Furthermore, we find a scientific contribution, as most of the students' work resulted in quality data that relates to knowledge gaps which are a problem for the Arba Minch community. Student science at a public university in a low-income country is feasible and can, as such, serve both scientific and educational needs. It is recommended that public universities in low-income contexts implement part of their curriculum goals in such projects.
\end{abstract}

Keywords: air quality, campus exposure, public university, Ethiopia, student measurements, practical university education, citizen science, student-teacher-scientist partnerships

\section{INTRODUCTION}

\section{Scientific Developments}

Within a low-income country such as Ethiopia, there is a paradox between a relatively heavy burden of disease due to air pollution (World Health Organization, 2018), and limited conventional (expensive) air quality monitoring equipment and research (Abraham \& Li, 2014; Rebeiro-Hargrave et al., 2020; Roychowdhury et al., 2016). Finding cheaper ways to research air quality can resolve this paradox. A means to this end is citizen science, i.e. the practice of science by people who are not affiliated with credentialed academic or research institutions (Kimura \& Kinchy, 2016), or science by lay people. Cheaper self-made instruments are being used (for example in Bulot et al., 2020; Jiang et al., 2016), and the data collectors might do the work voluntarily. In this way, for the same order of magnitude of data collection, less money is needed. Similarly, scientists involve students in science projects, as part of the students' curriculum (Evans et al., 2001; Houseal et al., 2014; Lawless \& Rock, 1998; McLaughlin et al., 2016; Peker \& Dolan, 2012; Wormstead et al., 2002).

\section{Educational Developments}

Involving students in science as part of their curriculum suits well to the recent educational paradigm which started in the 1980s by the USA National Committee on Excellence in Education (1983). The underlying belief was that the 'new workforce reality (...) demands (...) independent thinkers, problem solvers and decision makers' (Silva, 2009, p. 630), education must not just teach the basics and focus on knowledge accumulation, but education must make students gain thinking, working and reasoning skills (Silva, 2009). We encounter this idea also in Ethiopia's scientific community. At Ethiopia's second science congress, titled 'Re-envisioning Higher Education and Research in Ethiopia', Bililign (2015) argued that education should focus on core skills such as critical thinking, collaborative working, effective communication across disciplines and cultures, and learning how to (want to) learn. A format of such education is projectbased learning, in which 'students drive their own learning 
through inquiry, as well as work collaboratively to research and create projects that reflect their knowledge' (Bell, 2010, p. 39). In Ethiopia, a shift from theoretical-based education to practical and inquiry-based education is much needed. The current, often theoretical-based, education results in a gap between graduates' skills and employers' demands and may contribute to youth unemployment (Reda \& Gebre-Eyesus, 2018; Yibeltal Yizengaw, 2018).

\section{Student Science Combines Scientific \& Educational Goals}

When combining the above-described developments in science and education, one could argue that cooperation between scientists and students may result in a win-win situation. The scientist gets research assistants and measurement results and may be inspired by the creative input of her/his students. The students get a real-life problemsolving situation which will encourage inquiry-based learning, preparing them for being useful employees. This phenomenon, scientists and students working together to reach scientific and educational goals, is not new. The literature uses different terms: student scientist partnerships (SSPs) or student teacher scientist partnerships (STSPs) (Evans et al., 2001; Houseal et al., 2014; Lawless \& Rock, 1998; McLaughlin et al., 2016; Peker \& Dolan, 2012; Wormstead et al., 2002), Research apprenticeships (Sadler et al., 2009), and citizen science by students (Mitchell et al., 2017; Zoellick et al., 2012). Bililign (2015, p. 144) suggests the term research-based teaching for the Ethiopian context: 'In this approach courses are designed largely around inquiry-based activities, rather than on the acquisition of subject content'. To recognize that each of the different terms and related studies hold relevant aspects, not one of them is selected, but instead the term 'student science' (SS) is used. This term is chosen in line with the term citizen science, stressing the value of both scientific and educational goals, and with the knowledge that practical skills are reached when students are not only in partnerships with, but really are the scientists.

\section{Research Gap and Problem Statement}

Different SS projects have been subject to research. However, we could not find a published academic source evaluating such projects on public universities in low-income countries, even though the need for affordable data collection and practical education in low-income countries like Ethiopia is notable (Reda \& Gebre-Eyesus, 2018; Yibeltal Yizengaw, 2018). There is a gap in literature on the evaluation of SS projects in the context where budget for science is low and students are hardly practically trained. It is unknown whether this academic context impedes an SS project, or if an SS project is feasible and able to facilitate affordable data collection and practical training. Also, the scientific contribution of an SS project on a public university in a low-income country has not yet been evaluated in the literature. This leads to the following problem statement: there is a lack of insight in the feasibility and scientific contribution of involving students in research as part of their education on a public university in a low-income country. Therefore, this study wishes to evaluate the feasibly of an SS project, and its scientific contribution, in the context of a public university in a low-income country.

\section{Outline of the Study}

To determine the feasibility of an SS project, an 'ideal' SS project is defined, based on scientific and educational best practices in the literature. Next, a case study is conducted on an air quality SS project that took place at Arba Minch University, Ethiopia. This air quality SS project is evaluated on scientific and educational best practices, to investigate the feasibility of an SS project in a low-income country. Lastly, scientific contribution of the air quality SS project is evaluated.

\section{LITERATURE REVIEW}

Literature concerning science by lay people (citizens or students), with or without cooperation with scientists, is reviewed. Based on this literature, best practices for successful SS projects are described. We first address the scientific best practices, and next the educational best practices.

\section{Best Practices in Reaching Scientific Goals with SS}

Scientific goals of an SS project are that the students (i) obtain quality data and (ii) generate scientific knowledge (Lawless \& Rock, 1998). From the literature best practices to reach these scientific goals in an SS project are separated over five categories:

1. It is important to offer training to the students (AcevesBueno et al., 2015). There should be a standardized set of training sessions (Evans et al., 2001; Freitag \& Pfeffer, 2013). Part of this training should focus on the required precision and accuracy, as this will enhance data quality (Parrish et al., 2018).

2. Quality can be further assured when a plan of measurements is made before the start of data collection. This plan establishes what will be done, and how it will be done. For general tasks standardized research protocols and methodologies can be used (Aceves-Bueno et al., 2015; Evans et al., 2001; Freitag \& Pfeffer, 2013; Lawless \& Rock, 1998). A design specific to a certain topic is important to ensure the quality of tasks that cannot be generalized (Parrish et al., 2018).

3. Students should be supplied with adequate equipment: equipment that is relevant to the topic, and that is of adequate quality (Aceves-Bueno et al., 2015; Lawless \& Rock, 1998).

4. After data collection, data quality can be enhanced by validation of data (Parrish et al., 2018). Identification of potential sources of error will help in general (Lawless \& Rock, 1998). As for the data itself, questionable identifications can be checked by experts (AcevesBueno et al., 2015), or validated by multiple measurements (Lawless \& Rock, 1998). Student's selfawareness of data reliability is enhanced if students conduct peer reviews (Mitchell et al., 2017).

5. Throughout the whole process, data quality is enhanced if students have access to experts, through regular contact (Boersma \& Vroom, 2006; Evans et al., 2001; Lawless \& Rock, 1998) or collaboration (Freitag \& Pfeffer, 2013). 


\section{Best Practices in Reaching Educational Goals with SS}

To be an SS project, also educational goals need to be sought. These vary, and are related to the curriculum and to different skills to be trained. The best practices to reach educational goals with SS can be grouped into four main categories:

1. Curriculum's knowledge goals can be reached with SS, if the science project is in line with learning requirements (the student's curriculum) (Zoellick et al., 2012). Observing and empirically verifying knowledge claims of curricula, inquiry-based learning (Tafoya et al., 1980) will 'support (...) the integration of practices and concepts' (Houseal et al., 2014). Not only will this help to understand the concepts, but it might also alter the student's perception of the curriculum's topics. Ortiz (2018) has shown that students' perception on nature changed positively after joining a biology data collection project.

2. Inquiry-based learning can be an educational goal in itself. This means that students are trained in a scientific way of thinking and working. While traditionally the science curriculum included 'what one needs to know to do science', the newer perspective focuses on 'what students need to do to learn science' (Duschl, 2008, p. 269). When scientific practices are introduced earlier and more often in the curriculum, by letting students do authentic science, students will get an improved understanding of core science contents and have deeper engagement with science (Zoellick et al., 2012). Related to inquiry-based learning, the following best practices can be distinguished:

a. Realistic cases (real data and real scientific problems) rather than simplified and abstract cases should be used (Zoellick et al., 2012).

b. Teachers should not provide authoritarian answers. Students must learn that truth is based on observable science, rather than what the teacher says (Tafoya et al., 1980).

c. Expose the students to different instructional settings, and to a variety of materials and methods (Tafoya et al., 1980).

d. Involve the students not only in data acquisition, but also in the other aspects of scientific methods and research (Lawless \& Rock, 1998), such as the development of their own research question (RQ) (Evans et al., 2001).

3. It can be an educational goal to enhance students' motivation for conducting science. Literature suggests the following good practices to make students motivated to participate in the science project:

a. Give students access to experts. Evans et al. (2001) showed that students value access to experts. Working with an expert offers a unique opportunity for personal development (Freitag \& Pfeffer, 2013). Ozturk (2015) states that optimal communication with the scientist leads to a change in students' perception on science. b. Give feedback to the students. He et al. (2014) found that only giving positive feedback, and feedback with corrective guidance, encourages students to collect more data.

c. Show the outcome of the students' work in a larger context. This way they are able to see how their work contributed to the bigger picture (Parrish et al., 2018).

d. Make students owner of their work. Let them select and answer an RQ, which is driven by their curiosity rather than by 'what the teacher says' (Evans et al., 2001; Houseal et al., 2014).

4. A variety of educational goals can be related to the development of different practical skills.

The following practical skills are associated with SS projects:

1. Learning how to develop an RQ makes students think critically about research gaps (Evans et al., 2001).

2. Student peer reviews will make students collaborate and critically evaluate each other's and, in the end, their own work (Zoellick et al., 2012).

3. Presentation of the research trains communication and media literacy skills (Zoellick et al., 2012).

\section{MATERIALS AND METHODS}

\section{Introduction of the Case \\ Student science project set-up}

This study evaluated an air quality SS project for students of Water Supply and Environmental Engineering (WSEE; 139 students, year 4) and Meteorology and Hydrology (MHD; 26 students, year 2) at Arba Minch University (AMU), one of the public universities of Ethiopia. The course took one semester (October 2019-January 2020) and was offered by the first author of this article. He had a double role: lecturer and scientist/expert. We will consistently refer to him by using the term instructor.

In the SS project, students worked in groups of 4-6 (total 33 groups) on the full research cycle, investigating a selfselected scenario in which they noticed air pollution. The students could pick scenarios related to either carbon monoxide (CO; increased concentrations due to incomplete combustion), particulate matter with an aerodynamic diameter smaller than 2.5 (PM2.5; increased concentrations due to incomplete combustion) and/or carbon dioxide $\left(\mathrm{CO}_{2}\right.$; increased concentrations within rooms with people, i.e. ventilation parameter). They produced a measurement plan, collected and analyzed the data, wrote a measurement report and presented their work. The planning of the course is displayed in Table 1 . The project part of the course consisted of approximately 8 hours of introduction/explanation of all different parts, and 35 hours of working on those parts. The instructor was available for consultancy during 15 of these 35 hours. 
Table 1. General course outline of the case study

\begin{tabular}{ll}
\hline Week & Activity \\
\hline $1-4$ & Lectures, scenario selection, and draft measurement plan \\
\hline 5 & Feedback and finalize measurement plans \\
\hline $6-8$ & Lectures and measurements \\
\hline $9-11$ & Lectures and draft report \\
\hline 12 & Feedback draft report, finalize report, and presentations \\
\hline
\end{tabular}

\section{External validity of the case}

We assume this case represents public university settings in low-income countries for the following reasons. Firstly, AMU is a public university, working with limited budget and implementing harmonized guidelines from the Ministry of Science and Higher Education. The SS project fits the regular curriculum schedule and semester planning, and, except for measurement instruments ${ }^{1}$, all resources used were available inside the university. Secondly, the project did not select only brilliant or only poor students, because freshmen students are admitted to the program based on moderate entry test scores and all students of the sections participated. Thirdly, the students live in a typical campus setting, with dormitories, small restaurants, classrooms, and other study places, so it is reasonable to assume that students in other low-income public universities have similar access to measurement locations.

\section{Data collection methods}

The instruments available were the Lascar EL-USB-CO datalogger (for CO; from hereon: ELCO), the UCB-PATS+ (for PM2.5; from hereon: PATS) and the IQAir Airvisual Pro (for PM2.5 and/or $\mathrm{CO}_{2}$; from hereon: IQAV). All instruments were prepared by the instructor; students took the instruments while they were working, and only needed to use them at their chosen location. Tasks afterwards (such as data retrieval, zero calibrations, etcetera) were conducted by the instructor.

33 groups conducted a total of 65 measurements, as some of the groups collected multiple data files (for example, inside and outside a restaurant kitchen). The length of measurements ranged from 5 minutes to 5.75 hours (average and median: 1.7 hours), with measurement frequencies ranging from 10 seconds to 5 minutes. For this study, the 65 individual measurements have been ordered into groups that are in a similar situation: restaurants, households, waste burning, ambient environment, and ventilation. Table 2 shows a summary of the student measurements. Measurements in restaurants were held at different campus cafeterias, and one restaurant in Arba Minch town. Measurements at households were held at different households in Arba Minch. Measurements at waste burning sites were held close (CO 1-40 meter, PM2.5 1-20 meter) to burning of domestic or agricultural waste at the campus. Ambient measurements were conducted in Arba Minch bus station, outside the bus station, at the roadside close to campus, at a smoking area in campus an at the soccer field in campus. $\mathrm{CO}_{2}$ ventilation measurements were taken in different libraries in campus, some student dormitories, classrooms, and campus cafeterias.
Table 2. Summary of measurement characteristics with number of datafiles (NF), number of data points within these data files (ND), \& total measurement time in hours (NH)

\begin{tabular}{|c|c|c|c|c|c|c|}
\hline ID & Scenario & $\mathbf{P}$ & $\mathbf{I}$ & $\mathrm{N}_{\mathrm{F}}$ & $\mathrm{N}_{\mathrm{D}}$ & $\mathrm{N}_{\mathrm{H}}$ \\
\hline & Restaurants & & & & & \\
\hline $1 \mathrm{~A}$ & Visitor area & $\mathrm{CO}$ & ELCO & 5 & 1,139 & 9.3 \\
\hline$\overline{1 B}$ & Kitchen area & $\mathrm{CO}$ & ELCO & 15 & 4,584 & 24 \\
\hline \multirow[t]{2}{*}{$1 \mathrm{C}$} & Outside kitchen $^{\mathrm{a}}$ & $\mathrm{CO}$ & ELCO & 5 & 504 & 8.3 \\
\hline & Households & & & & & \\
\hline $2 \mathrm{~A}$ & Kitchen, wood fuel & $\mathrm{CO}$ & ELCO & 5 & 415 & 6.8 \\
\hline $2 \mathrm{~B}$ & Kitchen, electrified & $\mathrm{CO}$ & ELCO & 4 & 245 & 4.0 \\
\hline $2 \mathrm{C}$ & Coffee ceremony ${ }^{\mathrm{b}}$ inside & PM2.5 & IQAV & 1 & 360 & 1.0 \\
\hline $2 \mathrm{D}$ & Coffee ceremony outside & PM2.5 & IQAV & 1 & 360 & 1.0 \\
\hline \multirow[t]{2}{*}{$2 \mathrm{E}$} & Charcoal cooking outside & $\mathrm{CO}$ & ELCO & 1 & 60 & 1.0 \\
\hline & Waste burning & & & & & \\
\hline $3 \mathrm{~A}$ & $\mathrm{CO}$ & $\mathrm{CO}$ & ELCO & 4 & 1,020 & 6.9 \\
\hline \multirow[t]{2}{*}{$3 \mathrm{~B}$} & PM2.5 & PM2.5 & PATS & 1 & 121 & 2.0 \\
\hline & Ambient & & & & & \\
\hline $4 \mathrm{~A}$ & Busstation CO & $\mathrm{CO}$ & ELCO & 1 & 360 & 1.0 \\
\hline $4 \mathrm{~B}$ & Busstation PM2.5 & PM2.5 & IQAV & 1 & 243 & 2.0 \\
\hline $4 \mathrm{C}$ & $\begin{array}{l}\text { Outside } \\
\text { busstation/roadside }\end{array}$ & PM2.5 & $\begin{array}{l}\text { PATS (2), } \\
\text { IQAV (1) }\end{array}$ & 3 & 1,931 & 5.9 \\
\hline $4 \mathrm{D}$ & Generator $^{\mathrm{c}}$ & PM2.5 & PATS & 2 & 698 & 1.9 \\
\hline $4 \mathrm{E}$ & Smoking area & PM2.5 & PATS & 1 & 1,099 & 3.0 \\
\hline \multirow[t]{2}{*}{$4 \mathrm{~F}$} & Soccer field & PM2.5 & PATS & 2 & 130 & 2.1 \\
\hline & Ventilation & & & & & \\
\hline $5 \mathrm{~A}$ & Library & $\mathrm{CO}_{2}$ & IQAV & 3 & 1,027 & 9.0 \\
\hline $5 \mathrm{~B}$ & Dormitory & $\mathrm{CO}_{2}$ & IQAV & 3 & 547 & 7.8 \\
\hline $5 \mathrm{C}$ & Outside dormitory $^{\mathrm{a}}$ & $\mathrm{CO}_{2}$ & IQAV & 1 & 96 & 1.9 \\
\hline $5 \mathrm{D}$ & Classroom & $\mathrm{CO}_{2}$ & IQAV & 2 & 269 & 3.6 \\
\hline \multirow[t]{2}{*}{$5 \mathrm{E}$} & Restaurant & $\mathrm{CO}_{2}$ & IQAV & 4 & 2,223 & 9.0 \\
\hline & All & & & 65 & 17,431 & 112 \\
\hline
\end{tabular}

Note. P: Pollutant; I: Instrument; a Some groups conducted simultaneous measurements inside and outside for comparison; ${ }^{b}$ The Ethiopian coffee ceremony is the full process of roasting beans up to preparing and serving coffee, usually on a charcoal fire and often together with burning incense; 'One $<25 \mathrm{kVA}$ gasoline generator and one $42 \mathrm{kVA}$ diesel generator

\section{Evaluation of Best Practices for Reaching Scientific and Educational Goals}

First, the SS air quality project was compared to best practices as retrieved from the literature in the section literature review. For a full overview of the checklist, please consult Table 3 and Table 4 . The checklist was filled based on information from the instructor and course documents. Each determinant received a qualitative score: - (absent); + (partially present); or ++(fully present).

\section{Evaluation of the Scientific Contribution}

\section{Operationalization of scientific contribution}

A successful contribution to science can be described as obtaining quality data with which scientific knowledge is generated (Lawless \& Rock, 1998). Generating scientific knowledge can be further operationalized as filling a knowledge gap in relation to a problem for the community (Arkato et al., 2018).

\footnotetext{
${ }^{1}$ The instruments were part of a donation by Buro Blauw, an air quality consultancy company from the Netherlands. The combined costs of the instruments used in the project is approximately $\$ 4,200$ or ETB 220,000 (per February 2022), which is not beyond the research budget of a public university in Ethiopia. Hence, this donation does not rule out the possibility for other public universities to conduct a similar project.
} 
Table 3. Evaluation of the project versus best practices for reaching scientific goals with a qualitative score (S)

\begin{tabular}{|c|c|c|c|}
\hline & Best practices & $\mathbf{S}$ & Score explanation \\
\hline \multirow[t]{2}{*}{ 象 } & $\begin{array}{l}\text { 1. The training covers all parts of } \\
\text { the research cycle }\end{array}$ & & $\begin{array}{l}\text { Students got the following instruction materials: (1) measurement plan \& report instructions; (2) } \\
\text { measurement plan \& report example; (3) instrument instructions; (4) data analysis instructions and } \\
\text { practice in Microsoft Excel, and (5) feedback on measurement plan \& measurement report. } \\
\text { Formally, all elements of the research cycle were requested in the measurement plan (proposal } \\
\text { phase) and the report (analysis, conclusion \& recommendations). } \\
\text {-Within the measurement plan, the following steps of the research cycle were specifically requested: } \\
\text { background as reason to do research, RQ, \& methodology (consisting of data collection \& analysis). } \\
\text {-Within the report, the following steps of the research cycle were specifically requested: } \\
\text { background+RQ, methodology, results \& analysis, conclusions, \& recommendations. }\end{array}$ \\
\hline & $\begin{array}{l}\text { 2. Required precision and } \\
\text { accuracy }\end{array}$ & & $\begin{array}{l}\text { Students were informally encouraged to critically evaluate the quality of the data they collected } \\
\text { during the lectures and the consultancy hours. } \\
\text { No explicit instruction on precision and accuracy was given. }\end{array}$ \\
\hline \multirow[b]{2}{*}{$\frac{E}{\mathbb{a}}$} & $\begin{array}{l}\text { 3. Standardized research } \\
\text { protocols and methodologies }\end{array}$ & & $\begin{array}{l}\text { Next to the training materials described above, there was a text document with guidelines, framed as } \\
\text { 'advice', for the data collection (data collection protocol). } \\
\text { The content of this protocol was discussed during the lectures and the students got a hardcopy of } \\
\text { this document when picking up the measurement instrument. }\end{array}$ \\
\hline & $\begin{array}{l}\text { 4. Each group makes a } \\
\text { measurement plan }\end{array}$ & & $\begin{array}{l}\text { It was mandatory to write a measurement plan. } \\
\text { After one feedback \& improvement round, all, except one, measurement plans were deemed } \\
\text { sufficient to continue the project by executing the measurements. } \\
\text { The group with the insufficient measurement plan was forced by the instructor to use a more } \\
\text { adequate measurement instrument. }\end{array}$ \\
\hline \multirow[b]{2}{*}{ 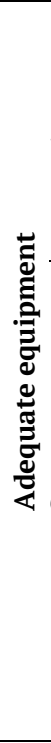 } & 5. Relevance of instruments & + & $\begin{array}{l}\text { Before approving the measurement plan, the instructor checked if the right instrument was chosen } \\
\text { for the right research scenario. } \\
\text { There were two cases in which the relevance of the instrument was doubtful: } \\
\text {-Within measurements of scenarios } 3 C \& 3 \mathrm{D} \text {, the maximum range of the IQ air was reached. } \\
\text { Hence, it is known that the concentration is high, but the precise concentration is unknown. } \\
\text {-For scenario 5C, one dataset of the PATS came back with continuously the lowest reported value. } \\
\text { Hence, it is known that the concentration is low, but the precise concentration is unknown. }\end{array}$ \\
\hline & 6. Quality of instruments & & $\begin{array}{l}\text { Both ELCO and PATS are frequently used in air quality studies with a focus on biomass burning } \\
\text { (Chowdhury et al., 2012; Kumar et al., 2015; Leavey et al., 2015; Ochieng et al., 2016; Pennise et al., } \\
\text { 2009; Rosa et al., 2014). } \\
\text { Curto et al. (2018) found correlations of } 0.82-0.89 \text { between ELCO and a reference instrument, and } \\
\text { intra-correlations of } 0.8-0.93 \text {, under field circumstances. } \\
\text { Pillarisetti et al. (2017) report an } \mathrm{R}^{2} \text { of } 0.99 \text { between the PATS and a reference instrument under } \\
\text { controlled circumstances, } \mathrm{R}^{2} \text { of } 0.9 \text { between PATS and a reference instrument and intra- } \mathrm{R}^{2} \text { of } 0.94 \\
\text { under field circumstances. } \\
\text { For PM2.5 with the IQAV, Massen et al. (2018) found a correlation coefficient with a reference } \\
\text { instrument of } 0.97 \text {. } \\
\text { For } \mathrm{CO}_{2} \text {, Petersen et al. (2018) found a measurement uncertainty of }<50 \mathrm{PPM,} \mathrm{given} \mathrm{instruments} \mathrm{are} \\
\text { calibrated for temperature influences (which is the case for a }-10 \text { to } 40^{\circ} \mathrm{C} \text { range). } \\
\text { Based on this, the quality of the instruments is deemed adequate. }\end{array}$ \\
\hline \multirow{4}{*}{ 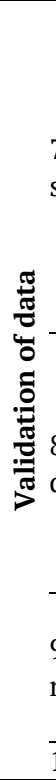 } & $\begin{array}{l}\text { 7. Identification potential } \\
\text { sources of error }\end{array}$ & & $\begin{array}{l}\text { To prevent instrumental errors, the procedures necessary to start and end the instruments were } \\
\text { conducted by the instructor. } \\
\text { Students collected and returned the instruments while the instruments were running. } \\
\text { The instructor retrieved the data from the instrument. } \\
\text { To prevent errors during the measurements, students had to follow the protocol described in this } \\
\text { table, row 3, which included guidelines like 'keep the instrument stable on a representative place'. } \\
\text { Next to this, there are pollutant-specific sources of error: the } \mathrm{CO}_{2} \text { sensor is sensitive to breathing } \\
\text { (for which the students were warned beforehand); in PM measurements, errors can arise when } \\
\text { aerosol is deliberately created; for CO measurements, no such manipulation is possible. }\end{array}$ \\
\hline & $\begin{array}{l}\text { 8. Identification of questionable } \\
\text { data }\end{array}$ & & $\begin{array}{l}\text { If the instructor observed unexpected peak values, the students were asked for an explanation. } \\
\text { For PM, one group deliberately blew dust in the sensor, so their data cannot be considered reliable } \\
\text { (scenario } 4 \mathrm{~F}) \text {. } \\
\text { For } \mathrm{CO} 2 \text {, some groups recognized that, at certain moments, someone was breathing close to the } \\
\text { sensor. Removal of values outside average }+2 * \text { std for } \mathrm{CO}_{2} \text { results in a more than } 10 \% \text { average change } \\
\text { for two } 5 \mathrm{~A} \text { measurements and one } 5 \mathrm{E} \text { datafile. } \\
\text { After being aware of these problems, the instructor could confidently prune the data. }\end{array}$ \\
\hline & $\begin{array}{l}\text { 9. Validating by multiple } \\
\text { measurements }\end{array}$ & & $\begin{array}{l}\text { Given the limited availability of instruments, validation by multiple measurements (same time and } \\
\text { place) was not done. } \\
\text { However, in the indirect quality assessment, discussed later in this article, the data was validated by } \\
\text { comparing it with data from similar studies described in the literature. }\end{array}$ \\
\hline & 10. Peer review & - & Peer review was not part of the course. \\
\hline & & & $\begin{array}{l}\text { The instructor has conducted research as part of his MSc study in the field of indoor air pollution, } \\
\text { and has been employed as air quality consultant in the Netherlands for } 5 \text { years. } \\
\text { There were } 15 \text { consultancy hours per class (especially during the weeks when the students were } \\
\text { working on their plan and report), all groups received written feedback on the measurement plan } \\
\text { and report, and for most of the groups this feedback was explained orally. }\end{array}$ \\
\hline
\end{tabular}


Table 4. Evaluation of the project versus best practices for reaching educational goals, with a qualitative score (S)

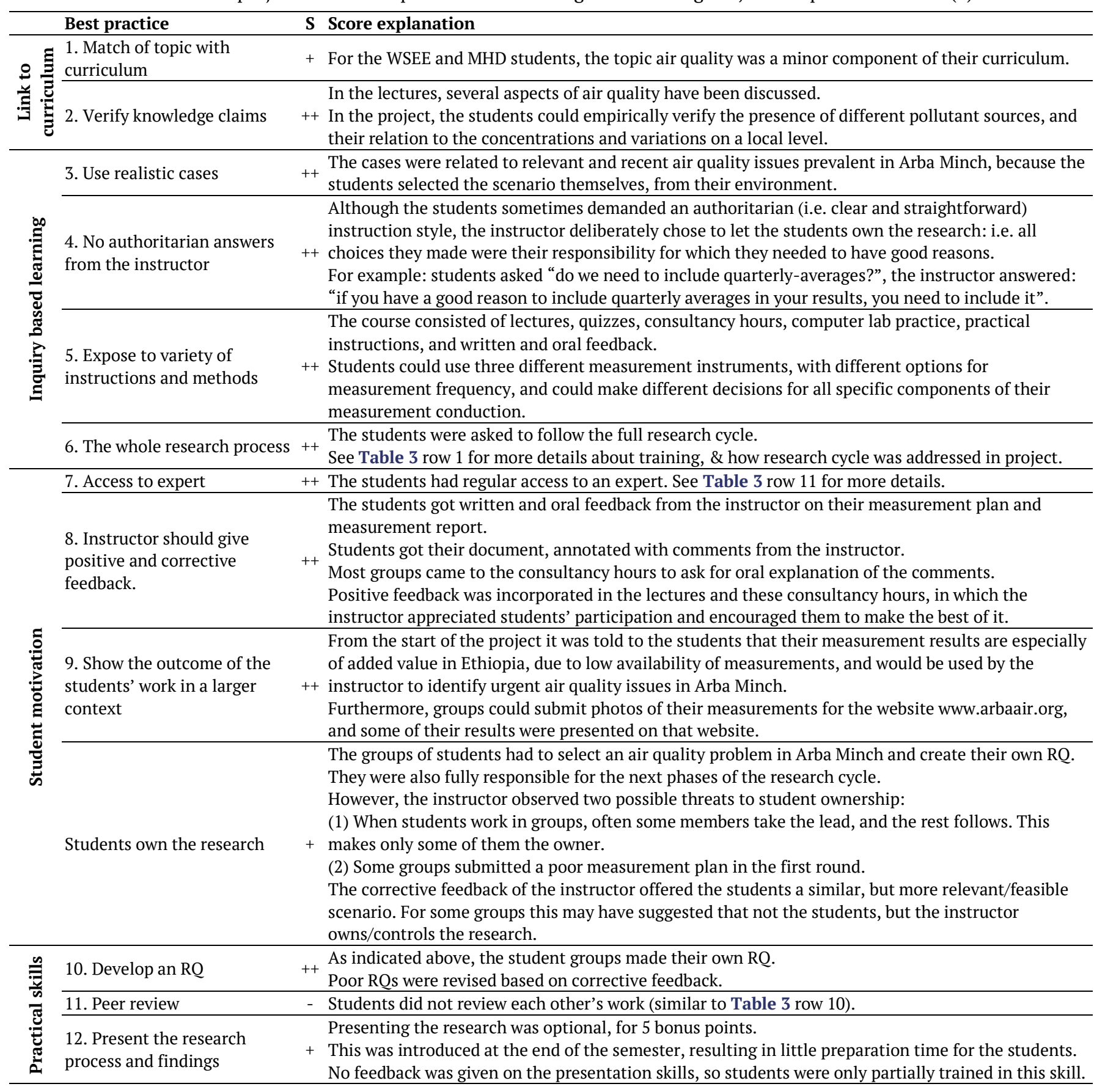

The SS project was evaluated based on those three points (data quality, knowledge gap, and problem for the community). For the analysis, all scenarios, except scenario $4 \mathrm{~F}$, were considered. Scenario $4 \mathrm{~F}$ was left out of the analysis due to disruption of the measurements. For two datafiles of scenario $5 \mathrm{~A}$ and one datafile of $5 \mathrm{E}$, all values higher than the average +2 *standard deviation (SD) were left out of the analysis, as these values were caused by breathing close to the sensor.

\section{Evaluation of the data quality}

To evaluate the data quality, measurement results were compared to reference values: measurement results from reference literature, or literature that is comparable to some extent. Comparison was conducted for three parameters: (i) the average of a scenario was compared to $R_{A v g} \pm R_{S t d}$, or, if $R_{S t d}$ was lacking, the range of $\mathrm{R}_{\mathrm{Min}}$ to $\mathrm{R}_{\mathrm{Max}}$; (ii) the average of a single measurement was compared to the range of $\mathrm{R}_{\text {Min }}$ to $\mathrm{R}_{\mathrm{Max}}$; and (iii) the standard deviation of a single measurements was compared to $\mathrm{R}_{\text {std. }}$. Different values were reported differently in different studies. In some studies, standard deviations based on the variation within a measurement ('within measurement') were mentioned. In others, standard deviations were based on different measurements ('over measurements'), which obviously were smaller than 'within measurements'. The student's data analysis only included the higher standard deviations (i.e., within measurements). Measurement results were evaluated as quality data if the averages fell within the range of reference values, and standard deviations were lower than $\mathrm{R}_{\text {std }}$ 's. 


\section{Evaluation of the knowledge gap}

To evaluate the knowledge gap for the different scenarios, literature on similar situations (reference literature) was reviewed. A knowledge gap was operationalized as either the absence of reference literature, or a large variation within reference literature (implying a large influence from local circumstances, i.e. a knowledge gap for another spatial setting). Variation was considered large if, for the values of the reference literature (reference values): (i) the reference standard deviation $\left(\mathrm{R}_{\mathrm{Std}}\right)$ was higher than $0.5^{*}$ the reference average $\left(R_{\text {Avg }}\right)$, or (ii) the range of reference values from minimum $\left(\mathrm{R}_{\mathrm{Min}}\right)$ to maximum $\left(\mathrm{R}_{\mathrm{Max}}\right)\left(\mathrm{R}_{\mathrm{Max}}-\mathrm{R}_{\mathrm{Min}}\right)$ was higher than $5 * \mathrm{R}_{\text {std. For }} \mathrm{R}_{\mathrm{Min}}$ and $\mathrm{R}_{\mathrm{Max}}$, only averages of full measurements (not values within measurements) were considered. All reference values are shown in Appendix A.

\section{Evaluation of the problem for the community}

To evaluate the problem for the community, the measurement results were compared to guideline values (GVs). Because there were different GVs, measurement results were calculated as a percentage relative to the relevant GV. For each scenario, a highest resulting percentage was presented. Scenarios were considered a problem for the community (worth investigating) if the resulting percentage was higher than 50\%. Calculated percentages for PM2.5 and $\mathrm{CO}_{2}$ were corrected for assumed background concentrations $\left(17 \mathrm{\mu g} / \mathrm{m}^{3}\right.$ for PM2.5 and 418 PPM for $\mathrm{CO}_{2}$ (Dingemanse, personal communication, July 17,2020 ); i.e., a measurement result of 418 PPM relative to the GV of 1,000 PPM was not $42 \%$, but $0 \%$. Instead, a measurement result of 709 PPM was considered as 50\%). GVs for CO were 87, 52, 26 and 9 PPM for time averages of respectively 15 minutes, 30 minutes, 1 hour and 8 hours (Environmental Protection Authority, 2003); similar time averages from measurement results were used for comparison.

For PM2.5, the World Health Organization (WHO) gives GV's of 25 and $10 \mu \mathrm{g} / \mathrm{m}^{3}$ for time averages of respectively 24 hours and 1 year (World Health Organization, 2006); the average PM2.5 concentration of a single measurement was translated to a 24-hour average based on a likely duration of the respective circumstance (scenarios $2 \mathrm{C}, 2 \mathrm{D}, 3 \mathrm{~B}, 4 \mathrm{D}$, and $4 \mathrm{E}$ : 1 hour; scenarios $4 \mathrm{~B}$ and $4 \mathrm{C}$ : 8 hours), and the assumed background concentration. For $\mathrm{CO}_{2}$, a GV of 1,000 PPM was based on advice with respect to indoor air quality and ventilation (OSSTF, 2020); the average of a single measurement was used for comparison.

\section{Data Processing and Availability}

All measurement data was processed with Python version 3.7.9 (Python Core Team, 2020), and all graphics were created with the Python library Matplotlib version 3.3.2 (Hunter, 2007).

The data generated and/or analyzed during the current study (project instruction documents, air quality measurement data and Python scripts) are available in the OSF repository, https://doi.org/10.17605/OSF.IO/C89X4.

\section{RESULTS}

\section{Best Practices for Reaching Scientific and Educational Goals}

Table 3 and Table 4 present the evaluation of the project for respectively scientific and educational goals. As can be seen in the tables, the case study scored well with respect to the best practices. Of the 24 best practices, 15 received full score, while 7 received a partial score, and only 2 were fully absent.

\section{Scientific Contribution of the SS Project}

\section{Data quality}

Figure 1 shows the range of literature reference measurements and the student measurements. Reference values were based on Appendix A. Measurement results are shown only for the scenarios, for which reference values could be obtained from literature. Of the 20 scenario averages, three ( $4 \mathrm{~A}, 4 \mathrm{D}$, and $5 \mathrm{D}$ ) were outside the range of $\mathrm{R}_{\mathrm{Avg}} \pm \mathrm{R}_{\mathrm{std}}$, while two of those, and another one (2C, $4 \mathrm{~A}$, and $4 \mathrm{D})$, were outside the range of $\mathrm{R}_{\mathrm{Min}}-\mathrm{R}_{\mathrm{Max}}$. For scenarios $2 \mathrm{C}$ and $4 \mathrm{D}$ an explanation for the deviation could be given (see Appendix A). Only 2 scenario averages were likely unreliable, while 11 were within range of reference values, 2 were outside range with explanation and 5 could not be validated due to lack of reference values.
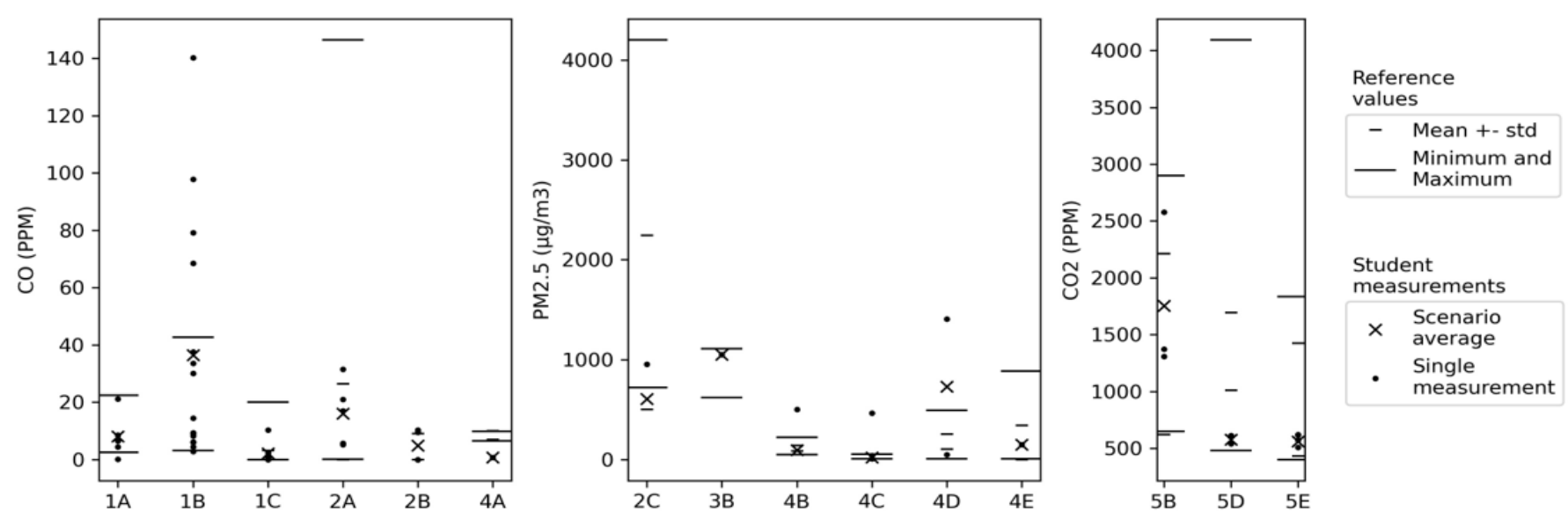

Figure 1. Range of literature reference values (RAvg \pm RStd and/or Rmin-Rmax value), and student measurement results (average per scenario and single measurement averages) 


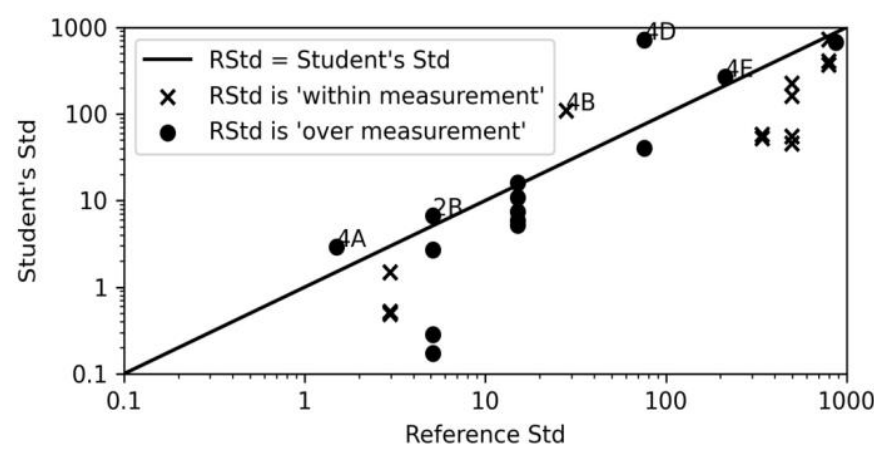

Figure 2. SDs of student measurements versus RStd

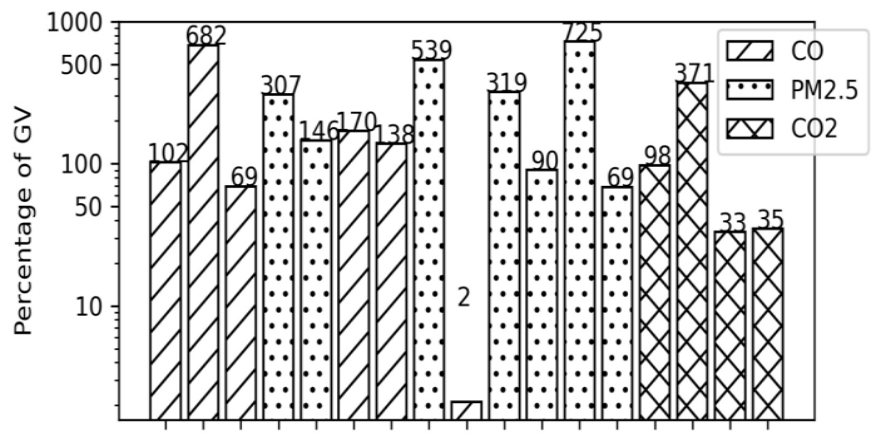

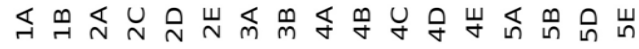

Figure 3. Highest measurements for scenarios relative to guideline values

Of the 63 single measurements, 9 were outside the range of reference measurements (1A: 1; 1B: 5; 2C: 1 ; $4 \mathrm{~A}: 1$; 4D: 1$)$. For scenarios $1 \mathrm{~B}, 2 \mathrm{C}$, and $4 \mathrm{D}$, an explanation for the deviation could be given (see Appendix A). Only 2 single measurements were likely unreliable, while 40 were within range of reference values, 7 were outside range with explanation and 14 could not be validated.

Figure 2 shows the standard deviations (SDs) of the single measurements versus the SDs of reference measurements. Of the 63 single measurements, only five had higher SDs than the reference values. Of these, four were compared to SDs over measurements (see Appendix A). Only 1 SD of single measurements was likely unreliable, while 21 were within range of reference values, 4 were outside range with explanation and 37 could not be validated.

\section{Problem for the community}

Figure 3 shows the highest measurement for each (relevant) scenario, relative to the respective guideline value. Scenarios $1 \mathrm{C}, 2 \mathrm{~B}$, and $5 \mathrm{C}$ were not considered as their comparison to GVs was not relevant (results are low due to the object of those scenarios' measurements). 3 of the 17 scenarios had values lower than $50 \%$ of the guideline value, 3 between $50-100 \%$, and the remaining 11 exceeded the guideline value. Among those with the highest percentages were restaurant kitchens (1B), coffee ceremony (2C), waste burning (3B), bus station (4B), generators (4D), and dormitory concentrations (5B).

\section{Knowledge gap}

Table 5 shows that for 18 out of 20 scenarios there was a research gap. For 9 scenarios there was a research gap, because no other studies had been done on this situation (NR). For the other 9 scenarios there was a research gap because the studies show measurements with large variations (LV), indicating that local measurements must be conducted to get insight in a local situation. For two scenarios there was no research gap (-), indicating that the air quality situation of the investigated phenomenon can also be predicted on the literature. For them, air quality measurements were not strictly necessary.

\section{DISCUSSION}

\section{Discussion of the SS Project}

A student science project can be a solution to both scientific and educational challenges in a low-income country such as Ethiopia. The evaluation of an SS project on Arba Minch University revealed that conducting an SS project is feasible, as most practices for reaching scientific and educational goals were met. Not all best practices were executed, most notably peer review. Peer review leads to a higher understanding of data quality by students (Mitchell et al., 2017), and review and rating between members leads to enhanced data quality as well (Hunter et al., 2013). Only after doing this research ex post the instructor is inspired to apply this (and other missed best practices) in the future.

Similarly, the provided overview of best practices and the in-depth insight in this case can offer inspiration for other lecturers at universities in low-income countries for the introduction of practical assignments in combination with conduction of research. The wider this is taken up, the deeper the connection with the curriculum is created, benefiting educational goals (Zoellick et al., 2012).

As access to experts is an important part to a successful SS project (Boersma \& Vroom, 2006; Evans et al., 2001; Freitag \& Pfeffer, 2013; Lawless \& Rock, 1998), successful execution depends on the expertise, motivation and available time of the instructor. The two-fold goal (scientific and education) requires input from both the expert and the curriculum (Zoellick et al., 2012), and implies distinct roles for a scientist and a teacher (providing expertise and providing access to it) (Peker \& Dolan, 2012). To make a fulfilment of these roles, with enough motivation and time, more likely, cooperation between different staffs and different courses is advisable.

The evaluation of this project also revealed that an SS project on a university in a low-income country can have relevant scientific contributions. For various other countries, scientific contributions are already proven through the mere fact that citizen science projects have resulted in several scientific publications (Mitchell et al., 2017). Data from such projects is 'largely valuable and (...) errors (...) can generally be fixed or accounted for.' (Aceves-Bueno et al., 2015, p. 503). A main challenge is the scientific use of gathered data (Conrad \& Hilchey, 2011).

The data collected in this SS project is used as input to distinguish priority areas in air quality research (article under submission), and data is publicly available at: https://doi.org/10.17605/OSF.IO/C89X4. 
Table 5. The research gap per scenario: no reference studies (NR), large variations (LV) or no research gap (-)

\section{Scenario Gap Explanation}

For restaurant air quality, with dominant use of biomass, no reference studies can be found.

Some studies had such kitchens as subject, but no air pollutant measurements were conducted (Juntarawijit \& Juntarawijit,

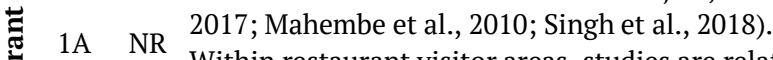

1B NR Within restaurant visitor areas, studies are related to smoking (for example, Konstantopoulou et al., 2014; Williams Jr et al.,

1B NR 2014), or to Chinese cooking styles, cooking oils \& deep frying (Lee et al., 2001; Lee et al., 2002; Zhao et al., 2010).

1C NR Only one study conducted measurements in a restaurant with biomass fuel (a charcoal barbecue restaurants), both in visitor areas and kitchens, but in these restaurants also gas appliances are used (Zhang et al., 2017), i.e. no dominant use of biomass as fuel, as was the case for scenarios $1 \mathrm{~A}$ through $1 \mathrm{C}$.

Several studies have been conducted within household kitchens during use of biomass fuels.

A Studies with CO measurements during cooking, with maximum averaging periods of 2 hours are reference studies (Clark et al.,

2A LV 2010; Khalequzzaman et al., 2011; Leavey et al., 2015; Mukhopadhyay et al., 2012).

There is however large variation $\left(\mathrm{R}_{\mathrm{std}}>0.5^{*} \mathrm{R}_{\mathrm{avg}}\right)$.

$2 \mathrm{~B} \mathrm{NR}$ In relation to electrification of the kitchen, two studies with measurements are focused on a longer period than only the

2B NR cooking period (Barron \& Torero, 2017; Rollin et al., 2004), while scenario 2B considered cooking only.

2C LV The Ethiopian coffee ceremony inside a house has been subject of one pilot study (Keil et al., 2010).

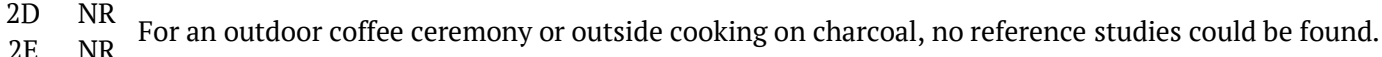

¿ $3 \mathrm{~A} \quad \mathrm{NR}$ For waste burning, no reference studies could be found.

3A NR The few studies that are concerned with concentrations from open waste burning, conducted measurements at a larger

3B NR distance (Baalbaki et al., 2018; Cheng et al., 2009; Sivertsen, 2006).

4A - In different bus stations across the world measurements have been conducted (Cheng et al., 2009; Razif \& Abib, 2006; Salama

4B LV et al., 2017). For PM2.5, there is a large variation ( $\left.\mathrm{R}_{\max }-\mathrm{R}_{\min }>5 * \mathrm{R}_{\mathrm{std}}\right)$.

\begin{tabular}{ll}
\hline 4C - $\quad \begin{array}{l}\text { Concentrations at roadsides/outside bus stations are monitored across the world. A study in which both a bus station \& } \\
\text { background concentrations were measured (Jamriska et al., 2005) is used as reference study. }\end{array}$ \\
For generators, different studies have been conducted (Giwa, 2019a; Giwa, 2019b; Oguntoke \& Adeyemi, 2017), in which large
\end{tabular}

$4 \mathrm{D}$ LV variations are found across age, fuel and size $\left(R_{\max }-R_{\min }>5 * R_{s t d}\right)$.

Diesel generators emit more than gasoline generators, and a higher power output generally also leads to higher emissions. For smoking, different studies have been conducted.

4E LV Some of these studies are used as reference studies (Brauer \& Mannetje, 1998; Williams Jr et al., 2014).

Variations are large $\left(\mathrm{R}_{\text {std }}>0.5 * \mathrm{R}_{\text {avg }}\right)$.

5A NR No reference studies with measurements are found for libraries.

For dormitories, several measurements have been conducted for an MSc thesis (Jenkins, 2018). Variations are large

5 $5 \mathrm{~B} \quad \mathrm{LV} \quad\left(\mathrm{R}_{\mathrm{std}}>0.5^{*} \mathrm{R}_{\text {avg }}\right)$.

5C LV Measurements outside the dormitories simply served for comparison with scenario 5B, hence the knowledge gap classification is similar.

5D LV For classrooms, several studies have been conducted (reported by Soomro et al., 2019). Variation is large $\left(R_{\max }-R_{\min }>5 * R_{s t d}\right)$.

5E LV For restaurants, reference studies can be found (Akbar-Khanzadeh et al., 2002; Zhang et al., 2017).

5E LV Variations are large $\left(\mathrm{R}_{\text {std }}>0.5 * \mathrm{R}_{\text {avg }}\right)$.

\section{Limitations and Recommendations}

The feasibility was evaluated based on a comparison with best practices. Evaluation of these best practices is ultimately a discipline-related matter. For disciplines other than local air pollution, other types of instruments, data quality goals and curriculum requirements might lead to another weight of the different best practices. While this study showed the feasibility of an SS project, this does not necessarily mean that any SS project for any discipline is feasible. This study has however provided a framework for evaluation of the feasibility of SS projects. Experts on public universities in low-income countries can set up SS projects in their respective disciplines and can study the feasibility of their specific project with this framework.

The broad scope of this study forced concessions on evaluating the scientific contribution of the students' work. The operationalization of the knowledge gap, data quality and the problem for the community are general. For aggregated citizen science data, Aceves-Bueno et al. (2017) find insufficient levels of accuracy, but this data might prove of higher quality if the comparison is conducted on a higher detail (Specht \& Lewandowski, 2018). A more detailed check of each scenario could enhance the assessment of the scientific contribution (e.g. the relevance of electrification (Barron \& Torero, 2017), studying specific variables influencing the different concentrations (Baumgartner et al., 2011; Kumie et al., 2009) such as ventilation (Zhang et al., 2015), stove types (Hu et al., 2014), or seasonal variations (Ni et al., 2016) to mention a few). Naturally, SS projects in other disciplines would require other checks with respect to their scientific contribution.

Lastly, next to evaluating the scientific contribution, there is a need for evaluating educational contributions of the SS project. While meeting educational best practices suggests positive educational contributions, this hypothesis has not yet been tested in the context of a public university in a lowincome country like Ethiopia. Methodologies used for such an evaluation are pre- and post-intervention surveys, tests, interviews, questionnaires, or even observation (Houseal et al., 2014; Lasen et al., 2014; McLaughlin et al., 2016; Mitchell et al., 2017; Sadler et al., 2009). All these methods need to be planned together with the SS project. 


\section{CONCLUSION}

This study evaluated the feasibility and scientific contribution of a Student Science project on a public university in a low-income country. With respect to feasibility, it is found that the best practices for successful SS-like projects, education and scientific-wise, could be executed in the case of Arba Minch University (Ethiopia). As for scientific contribution, it is found that most student groups gathered quality data, related to a knowledge gap which is a problem for the community. Therefore, we can conclude that an SS project at a public university, in the context of a low-income country, is feasible and can lead to a useful scientific contribution. This SS project created more insight in the Ethiopian air quality situation, a field for which not yet many studies and funds are available, while, at the same time, it offered students training in inquiry-based thinking and other practical skills. It is recommended that public universities in low-income contexts implement part of their curriculum goals in such projects.

Author contributions: All co-authors have involved in all stages of this study while preparing the final version. They all agree with the results and conclusions.

Funding: No external funding is received for this article.

Acknowledgements: The authors would like to thank to Buro Blauw B.V. (air quality consultancy company from the Netherlands) for donating the measurement instruments that could be used in the Student Science Project. The authors would like to thank to students of WSEE year 4 and MHD year 2 $2019 / 2020$, as due to their motivation and care those instruments have been put to good use, without any damage to the instruments. The authors would also like to thank to Ir. Frans de Bree and Maria Baarslag for proofreading this article.

Declaration of interest: The authors declare that they have no competing interests.

Ethics approval and consent to participate: Not applicable. Availability of data and materials: All data generated or analyzed during this study are available at: https://doi.org/10.17605/OSF.IO/C89X4.

\section{REFERENCES}

Abraham, S., \& Li, X. (2014). A cost-effective wireless sensor network system for indoor air quality monitoring applications. Procedia Computer Science, 34, 165-171. https://doi.org/10.1016/j.procs.2014.07.090

Aceves-Bueno, E., Adeleye, A. S., Bradley, D., Brandt, W. T., Callery, P., Feraud, M., Garner, K. L., Gentry, R., Huang, Y., McCullough, I., Pearlman, I., Sutherland, S. A., Wilkinson, W., Yang, Y., Zink, T., Anderson, S. E., \& Tague, C. (2015). Citizen science as an approach for overcoming insufficient monitoring and inadequate stakeholder buy-in in adaptive management: Criteria and evidence. Ecosystems, 18(3), 493-506. https://doi.org/10.1007/s10021-015-9842-4

Aceves-Bueno, E., Adeleye, A. S., Feraud, M., Huang, Y., Tao, M., Yang, Y., \& Anderson, S. E. (2017). The accuracy of citizen science data: A quantitative review. The Bulletin of the Ecological Society of America, 98(4), 278-290. https://doi.org/10.1002/bes2.1336
Akbar-Khanzadeh, F., Tan, Y., Brown, E. N., \& AkbarKhanzadeh, M. (2002). An evaluation of ventilation system flow rates and levels of carbon dioxide, ambient temperature, and relative humidity in restaurants. Applied Occupational and Environmental Hygiene, 17(9), 640-647. https://doi.org/10.1080/10473220290095989

Arkato, A., Hailemariam, T., \& Alemu, T. (2018). AMU research guideline, revised, 2018. Arba Minch University.

Baalbaki, R., El Hage, R., Nassar, J., Gerard, J., Saliba, N. B., Zaarour, R., Abboud, M., Farah, W., Khalaf-Kairouz, L., Shihadeh, A. L., \& Saliba, N. A. (2018). Exposure to atmospheric PMS, PAHS, PCDD/FS and metals near an open air waste burning site in Beirut. Lebanese Science Journal, 19(2), 135-149. https://doi.org/10.22453/LSJ-017. 2.091103

Barron, M., \& Torero, M. (2017). Household electrification and indoor air pollution. Journal of Environmental Economics and Management, 86, 81-92. https://doi.org/10.1016/j. jeem.2017.07.007

Baumgartner, J., Schauer, J. J., Ezzati, M., Lu, L., Cheng, C., Patz, J., \& Bautista, L. E. (2011). Patterns and predictors of personal exposure to indoor air pollution from biomass combustion among women and children in rural China. Indoor Air, 21(6), 479-488. https://doi.org/10.1111/j.16000668.2011.00730.x

Bell, S. (2010). Project-based learning for the 21st century: Skills for the future. The Clearing House, 83(2), 39-43. https://doi.org/10.1080/00098650903505415

Bililign, S. (2015). Integrating research and education and recruiting and training of undergraduate research assistants. In the 2nd Science Congress of the Ethiopian Academy of Sciences Re-envisioning Higher Education and Research in Ethiopia (pp. 142-148).

Boersma, K. F., \& Vroom, J. P. de. (2006). Validation of MODIS aerosol observations over the Netherlands with GLOBE student measurements. Journal of Geophysical Research: Atmospheres, 111(D20). https://doi.org/10.1029/ 2006JD007172

Brauer, M., \& Mannetje, A. (1998). Restaurant smoking restrictions and environmental tobacco smoke exposure. American Journal of Public Health, 88(12), 1834-1836. https://doi.org/10.2105/AJPH.88.12.1834

Bulot, F. M. J., Russell, H. S., Rezaei, M., Johnson, M. S., Ossont, S. J. J., Morris, A. K. R., Basford, P. J., Easton, N. H. C., Foster, G. L., Loxham, M., \& Cox, S. J. (2020). Laboratory comparison of low-cost particulate matter sensors to measure transient events of pollution. Sensors, 20(8), 2219. https://doi.org/10.3390/s20082219

Cheng, M.-T., Horng, C.-L., Su, Y.-R., Lin, L.-K., Lin, Y.-C., \& Chou, C. C.-K. (2009). Particulate matter characteristics during agricultural waste burning in Taichung City, Taiwan. Journal of Hazardous Materials, 165(1), 187-192. https://doi.org/10.1016/j.jhazmat.2008.09.101

Cheng, Y.-H., Chang, H.-P., \& Hsieh, C.-J. (2011). Short-term exposure to PM10, PM2.5, ultrafine particles and CO2 for passengers at an intercity bus terminal. Atmospheric Environment, 45(12), 2034-2042. https://doi.org/10.1016/ j.atmosenv.2011.01.061 
Chowdhury, Z., Le, L. T., Masud, A. A., Chang, K. C., Alauddin, M., Hossain, M., Zakaria, A. B. M. M., \& Hopke, P. K. (2012). Quantification of indoor air pollution from using cookstoves and estimation of its health effects on adult women in Northwest Bangladesh. Aerosol and Air Quality Research, 12(4), 463-475. https://doi.org/10.4209/aaqr. 2011.10.0161

Clark, M. L., Reynolds, S. J., Burch, J. B., Conway, S., Bachand, A. M., \& Peel, J. L. (2010). Indoor air pollution, cookstove quality, and housing characteristics in two Honduran communities. Environmental Research, 110(1), 12-18. https://doi.org/10.1016/j.envres.2009.10.008

Conrad, C. C., \& Hilchey, K. G. (2011). A review of citizen science and community-based environmental monitoring: Issues and opportunities. Environmental Monitoring and Assessment, 176(1-4), 273-291. https://doi.org/10.1007/ s10661-010-1582-5

Curto, A., Donaire-Gonzalez, D., Barrera-Gómez, J., Marshall, J. D., Nieuwenhuijsen, M. J., Wellenius, G. A., \& Tonne, C. (2018). Performance of low-cost monitors to assess household air pollution. Environmental Research, 163, 5363. https://doi.org/10.1016/j.envres.2018.01.024

Dingemanse, J. D. (2020, July 17). Measurements from December 24, 2019 to March 30, 2020, with an IQ Air Airvisual Pro, in front of a home in Arba Minch.

Duschl, R. (2008). Science education in three-part harmony: Balancing conceptual, epistemic, and social learning goals. Review of Research in Education, 32, 268-291. https://doi.org/10.3102/0091732X07309371

Environmental Protection Authority. (2003). Guideline ambient environment standards for Ethiopia. https://plasticsdb. surrey.ac.uk/documents/Ethiopia/Republic\%20of\%20Ethi opia\%20EPA\%20(2003)\%20Ambient\%20Environment\%20 Standards\%20for\%20Ethiopia.pdf

Evans, C. A., Abrams, E. D., Rock, B. N., \& Spencer, S. L. (2001). Student/scientist partnerships: A teachers' guide to evaluating the critical components. The American Biology Teacher, 63(5), 318-323. https://doi.org/10.2307/4451118

Freitag, A., \& Pfeffer, M. J. (2013). Process, not product: Investigating recommendations for improving citizen science "success." PLoS ONE, 8(5), 664079. https://doi.org/10.1371/journal.pone.0064079

Giwa, S. O., Nwaokocha, C. N., \& Adeyemi, H. O. (2019a). Noise and emission characterization of off-grid diesel-powered generators in Nigeria. Management of Environmental Quality, 30(4), 783-802. https://doi.org/10.1108/MEQ-072018-0120

Giwa, S. O., Nwaokocha, C. N., \& Samuel, D. O. (2019b). Offgrid gasoline-powered generators: Pollutants' footprints and health risk assessment in Nigeria. Energy Sources, Part A: Recovery, Utilization, and Environmental Effects, 1-18. https://doi.org/10.1080/15567036.2019.1671555

He, Y., Bowser, A., Preece, J., Hansen, D., Boston, C., \& Hammock, J. (2014). The effect of individualized feedback on college students' contributions to citizen science. CSCW'14 Companion, 165-168. https://doi.org/10.1145/ 2556420.2556484
Houseal, A. K., Abd-El-Khalick, F., \& Destefano, L. (2014). Impact of a student-teacher-scientist partnership on students' and teachers' content knowledge, attitudes toward science, and pedagogical practices. Journal of Research in Science Teaching, 51(1), 84-115. https://doi.org/10.1002/tea.21126

Hu, W., Downward, G. S., Reiss, B., Xu, J., Bassig, B. A., Hosgood, H. D., Zhang, L., Seow, W. J., Wu, G., Chapman, R. S., Tian, L., Wei, F., Vermeulen, R., Lan, Q., Dean Hosgood, H., Zhang, L., Seow, W. J., Wu, G., Chapman, R. S., ... Lan, Q. (2014). Personal and indoor PM2.5 exposure from burning solid fuels in vented and unvented stoves in a rural region of China with a high incidence of lung cancer. Environmental Science and Technology, 48(15), 8456-8464. https://doi.org/10.1021/es502201s

Hunter, J. D. (2007). Matplotlib: A 2D graphics environment. Computing in Science \& Engineering, 9(3), 90-95. https://doi.org/10.1109/MCSE.2007.55

Hunter, J., Alabri, A., \& van Ingen, C. (2013). Assessing the quality and trustworthiness of citizen science data. Concurrency and Computation: Practice and Experience, 25(4), 454-466. https://doi.org/10.1002/cpe.2923

Jamriska, M., Madl, P., Morawska, L., \& Yip, M. (2005). Airborne particulate matter at a bus station: Concentration levels and governing parameters. In Proceedings of the 10th International Conference on Indoor Air Quality and Climate (pp. 1631-1635).

Jenkins, S. T. (2018). Ventilation impact on airborne transmission of respiratory illness in student dormitories [Master thesis, University of Maryland]. https://search. proquest.com/openview/c31ccbf82afb5c606e961d05f5d14 cbe $/ 1$ ?pq-origsite $=$ gscholar $\& \mathrm{cbl}=18750 \&$ diss $=y$

Jiang, Q., Kresin, F., Bregt, A. K., Kooistra, L., Pareschi, E., van Putten, E., Volten, H., \& Wesseling, J. (2016). Citizen sensing for improved urban environmental monitoring. Journal of Sensors, 2016, 1-9. https://doi.org/10.1155/ 2016/5656245

Juntarawijit, C., \& Juntarawijit, Y. (2017). Cooking smoke and respiratory symptoms of restaurant workers in Thailand. BMC Pulmonary Medicine, 17(41), 1-11. https://doi.org/10. 1186/s12890-017-0385-7

Keil, C., Kassa, H., Brown, A., Kumie, A., \& Tefera, W. (2010). Inhalation exposures to particulate matter and carbon monoxide during Ethiopian coffee ceremonies in Addis Ababa: A pilot study. Journal of Environmental and Public Health, 2010, 1-8. https://doi.org/10.1155/2010/213960

Khalequzzaman, M., Kamijima, M., Sakai, K., Ebara, T., Bilqis, Hoque, A., \& Nakajima, T. (2011). Indoor air pollution and health of children in biomass fuel-using households of Bangladesh: Comparison between urban and rural areas. Environmental Health and Preventive Medicine, 16, 375-383. https://doi.org/10.1007/s12199-011-0208-z

Kimura, A. H., \& Kinchy, A. (2016). Citizen science: Probing the virtues and contexts of participatory research. Engaging Science, Technology, and Society, 2, 331. https://doi.org/10. 17351/ests2016.99 
Konstantopoulou, S. S., Behrakis, P. K., Lazaris, A. C., \& Nicolopoulou-Stamati, P. (2014). Indoor air quality in a bar/restaurant before and after the smoking ban in Athens, Greece. Science of The Total Environment, 476, 136-143. https://doi.org/10.1016/j.scitotenv.2013.11.129

Kumar, R., Singh, K., Nagar, S., Kumar, M., Mehto, U. K., Rai, G., \& Gupta, N. (2015). Pollutant levels at cooking place and their association with respiratory symptoms in women in a rural area of Delhi-NCR. The Indian Journal of Chest Diseases \& Allied Sciences, 57(4), 225-231. https://www. vpci.org.in/uploads/Ariticle\%20_\%203_\%200A_2.pdf

Kumie, A., Emmelin, A., Wahlberg, S., Berhane, Y., Ali, A., Mekonen, E., Worku, A., \& Brandstrom, D. (2009). Sources of variation for indoor nitrogen dioxide in rural residences of Ethiopia. Environmental Health: A Global Access Science Source, 8(1), 1-11. https://doi.org/10.1186/1476-069X-8-51

Lasen, M., Jackson, C., Beavan, A., Johnson, B., \& Callin, R. (2014). An investigation of secondary students' engagement in a science inquiry through a student-scientist partnership [Paper presentation]. International Conference of STEM in Education. From: STEM 2014: International Conference of STEM in Education, Vancouver, BC, Canada. https://researchonline.jcu.edu.au/32769/

Lawless, J. G., \& Rock, B. N. (1998). Student scientist partnerships and data quality. Journal of Science Education and Technology, 7(1), 5-13. https://doi.org/10.1023/ A:1022575914118

Leavey, A., Londeree, J., Priyadarshini, P., Puppala, J., Schechtman, K. B., Yadama, G., Biswas, P., \& Warren, G. (2015). Real-time particulate and CO concentrations from cookstoves in rural households in Udaipur, India. Environmental Science \& Technology, 49, 7423-7431. https://doi.org/10.1021/acs.est.5b02139

Lee, S. C., Li, W.-M., \& Yin Chan, L. (2001). Indoor air quality at restaurants with different styles of cooking in metropolitan Hong Kong. Science of The Total Environment, 279(1-3), 181-193. https://doi.org/10.1016/S00489697(01)00765-3

Lee, S.-C., Guo, H., Li, W.-M., \& Chan, L.-Y. (2002). Intercomparison of air pollutant concentrations in different indoor environments in Hong Kong. Atmospheric Environment, 36(12), 1929-1940. https://doi.org/10.1016/ S1352-2310(02)00176-0

Mahembe, A., Mkoma, S. L., \& Kinambo, J. L. (2010). Cooking fuels and respiratory symptoms in kitchen workers in Morogoro Municipality, Tanzania. International Journal of Biological and Chemical Sciences, 4(4). https://doi.org/ 10.4314/ijbcs.v4i4.63037

Massen, F., Tholl, R., \& Zimmer, M. (2018). A short study in fine particles measurement at meteoLCD by inexpensive LLS sensors. Lycée Classique de Diekirch [Diekirch Classical High School]. https://meteo.lcd.lu/papers/short_study_fine _particles_19NOV2018.pdf

McLaughlin, C. A., Broo, J., MacFadden, B. J., \& Moran, S. (2016). Not looking a gift horse in the mouth: Exploring the merits of a student-teacher-scientist partnership. Journal of Biological Education, 50(2), 174-184. https://doi.org/ 10.1080/00219266.2015.1028571
Mitchell, N., Triska, M., Liberatore, A., Ashcroft, L., Weatherill, R., \& Longnecker, N. (2017). Benefits and challenges of incorporating citizen science into university education. PLOS ONE, 12(11), e0186285. https://doi.org/10.1371/ journal.pone.0186285

Mukhopadhyay, R., Sambandam, S., Pillarisetti, A., Jack, D., Mukhopadhyay, K., Balakrishnan, K., Vaswani, M., Bates, M. N., Kinney, PatrickL., Arora, N., \& Smith, KirkR. (2012). Cooking practices, air quality, and the acceptability of advanced cookstoves in Haryana, India: An exploratory study to inform large-scale interventions. Global Health Action, 5(1), 19016-19016. https://doi.org/10.3402/gha. v5i0.19016

National Commission on Excellence in Education. (1983, July). A nation at risk. Communications of the ACM, 26(7), 467478. https://doi.org/10.1145/358150.358154

Ni, K., Carter, E., Schauer, J. J., Ezzati, M., Zhang, Y., Niu, H., Lai, A. M., Shan, M., Wang, Y., Yang, X., \& Baumgartner, J. (2016). Seasonal variation in outdoor, indoor, and personal air pollution exposures of women using wood stoves in the Tibetan Plateau: Baseline assessment for an energy intervention study. Environment International, 94, 449-457. https://doi.org/10.1016/j.envint.2016.05.029

Ochieng, C., Vardoulakis, S., \& Tonne, C. (2016). Household air pollution following replacement of traditional open fire with an improved rocket type cookstove. Science of the Total Environment, 580, 440-447. https://doi.org/10.1016/ j.scitotenv.2016.10.233

Oguntoke, O., \& Adeyemi, A. (2017). Degradation of urban environment and human health by emissions from fossilfuel combusting electricity generators in Abeokuta metropolis, Nigeria. Indoor and Built Environment, 26(4), 538-550. https://doi.org/10.1177/1420326X16629818

Ortiz, J. L., Conkey, A. A. T., Brennan, L. A., Fedynich, L. V., \& Green, M. (2018). Wild birds in the classroom: Evaluation of student affinities, perceptions, and attitudes in response to an experiential curriculum. International Journal of Environmental \& Science Education, 13(10), 787-803. http://www.ijese.net/makale/2088.html

OSSTF. (2020). Inadequate ventilation and high CO2 levels. Ontario Secondary School Teachers' Federation. https://www.osstf.on.ca/en-CA/services/healthsafety/information-bulletins/inadequate-ventilation-andhigh-co2-levels.aspx

Ozturk, G. (2015). The broader impact of student-scientist partnership: Scientists' contribution to student's understanding and proficiencies of science $[\mathrm{PhD}$ thesis, Texas A\&M University]. https://oaktrust.library.tamu.edu/ handle/1969.1/155639

Parrish, J. K., Burgess, H., Weltzin, J. F., Fortson, L., Wiggins, A., \& Simmons, B. (2018). Exposing the science in citizen science: Fitness to purpose and intentional design. Integrative and Comparative Biology, 58(1), 150-160. https://doi.org/10.1093/icb/icy032 
Peker, D., \& Dolan, E. (2012). Helping students make meaning of authentic investigations: Findings from a studentteacher-scientist partnership. Cultural Studies of Science Education, 7(1), 223-244. https://doi.org/10.1007/s11422012-9385-3

Pennise, D., Brant, S., Mahu Agbeve, S., Quaye, W., Mengesha, F., Tadele, W., \& Wofchuck, T. (2009). Indoor air quality impacts of an improved wood stove in Ghana and an ethanol stove in Ethiopia. Energy for Sustainable Development, 13, 71-76. https://doi.org/10.1016/j.esd.2009 .04 .003

Petersen, J., Kristensen, J., Elarga, H., Andersen, R. K., \& Midtstraum, A. (2018). Accuracy and air temperature dependency of commercial low-cost NDIR CO2 sensors: An experimental investigation. In 4th International Conference On Building Energy \& Environment (pp. 203-207). https://backend.orbit.dtu.dk/ws/portalfiles/portal/146097 852/Untitled.pdf

Pillarisetti, A., Allen, T., Ruiz-Mercado, I., Edwards, R., Chowdhury, Z., Garland, C., Hill, L. D., Johnson, M., Litton, C. D., Lam, N. L., Pennise, D., \& Smith, K. R. (2017). Small, smart, fast, and cheap: Microchip-based sensors to estimate air pollution exposures in rural households. Sensors, 17(8), 1879. https://doi.org/10.3390/s17081879

Python Core Team. (2020). Python: A dynamic, open source programming language. (3.7.9) [Computer software]. www.python.org

Razif, M., \& Abib, A. (2006). Particulate matter concentration at the intercity bus station of Surabaya, Indonesia. Journal of Applied Sciences in Environmental Sanitation, 1, 31-35. http://portalgaruda.fti.unissula.ac.id/index.php?ref=brow se \&mod=viewarticle \&article $=70947$

Rebeiro-Hargrave, A., Motlagh, N. H., Varjonen, S., Lagerspetz, E., Nurmi, P., \& Tarkoma, S. (2020). MegaSense: Cyber-physical system for real-time urban air quality monitoring. In the 15th IEEE Conference on Industrial Electronics and Applications. https://doi.org/10.1109/ICIEA48937.2020.9248143

Reda, N. W., \& Gebre-Eyesus, M. T. (2018). Graduate unemployment in Ethiopia: The 'red flag' and its implications. International Journal of African Higher Education, 5(1). https://doi.org/10.6017/ijahe.v5i1.10967

Rollin, H. B., Mathee, A., Bruce, N., Levin, J., \& von Schirnding, Y. E. R. (2004). Comparison of indoor air quality in electrified and un-electrified dwellings in rural South African villages. Indoor Air, 14(3), 208-216. https://doi.org/10.1111/j.1600-0668.2004.00238.x

Rosa, G., Majorin, F., Boisson, S., Barstow, C., \& Johnson, M. (2014). Assessing the impact of water filters and improved cook stoves on drinking water quality and household air pollution: A randomised controlled trial in Rwanda. PLoS ONE, 9(3), 91011-91011. https://doi.org/10.1371/journal. pone.0091011

Roychowdhury, A., Chandola, P., \& Chattopadhyaya, V. (2016). Urban air quality management in Ethiopia: A guidance framework. Centre for Science and Environment.
Sadler, T. D., Burgin, S., McKinney, L., \& Ponjuan, L. (2009). Learning science through research apprenticeships: A critical review of the literature. Journal of Research in Science Teaching, 47(3), 235-256. https://doi.org/10.1002/ tea.20326

Salama, K. F., Alhajri, R. F., \& Al-Anazi, A. A. (2017). Assessment of air quality in bus terminal stations in Eastern province, Kingdom of Saudi Arabia. International Journal of Community Medicine and Public Health, 4, 1413. https://doi.org/10.18203/2394-6040.ijcmph20171748

Silva, E. (2009). Measuring skills for 21st-century learning. Phi Delta Kappan, 90(9), 630-634. https://doi.org/10.1177/ 003172170909000905

Singh, A., Kamal, R., Tiwari, R., Gaur, V. K., Bihari, V., Satyanarayana, G. N. V., Patel, D. K., Azeez, P. A., Srivastava, V., \& Ansari, A. (2018). Association between PAHs biomarkers and kidney injury biomarkers among kitchen workers with microalbuminuria: A cross-sectional pilot study. Clinica Chimica Acta, 487, 349-356. https://doi.org/10.1016/j.cca.2018.10.021

Sivertsen, B. (2006). Air pollution impacts from open air burning. WIT Transactions on Ecology and the Environment, 92. https://doi.org/10.2495/WM060471

Soomro, M. A., Memon, S. A., Shaikh, M. M., \& Channa, A. (2019). Indoor air CO2 assessment of classrooms of educational institutes of hyderabad city and its comparison with other countries. AIP Conference Proceedings, 020014. https://doi.org/10.1063/1.5115373

Specht, H., \& Lewandowski, E. (2018). Biased assumptions and oversimplifications in evaluations of citizen science data quality. Bulletin of the Ecological Society of America, 99(2), 251-256. https://doi.org/10.1002/bes2.1388

Tafoya, E., Sunai, D. W., \& Knecht, P. (1980). Assessing inquiry potential: A tool for curriculum decision makers. Journal of School Science and Mathematics, 80, 43-48. https://doi.org/ 10.1111/j.1949-8594.1980.tb09559.x

Williams Jr, R. D., Barnes, J. T., Hall, M. E., Day, T. F., \& Hunt, B. P. (2014). Analysis of restaurant indoor air quality in smoking-allowed vs. smoke-free college communities. American Journal of Health Studies, 29(1), 174-180. https://doi.org/10.47779/ajhs.2014.209

World Health Organization. (2006). WHO air quality guidelines for particulate matter, ozone, nitrogen dioxide and sulfur dioxide: Global update 2005. https://apps.who.int/iris/ handle/10665/69477

World Health Organization. (2018, May). Household air pollution and health. https://www.who.int/news-room/ fact-sheets/detail/household-air-pollution-and-health

Wormstead, S. J., Becker, M. L., \& Congalton, R. G. (2002). Tools for successful student-teacher-scientist partnerships. Journal of Science Education and Technology, 11(3), 277-287. https://doi.org/10.1023/A:1016076603759

Yibeltal Yizengaw, J. (2018). Skills gaps and mismatches: Private sector expectations of engineering graduates in Ethiopia. IDS Bulletin, 49, 5. https://doi.org/10.19088/ 1968-2018.174 
Zhang, W., Wang, L., Ji, Z., Ma, L., \& Hui, Y. (2015). Test on ventilation rates of dormitories and offices in university by the CO2 tracer gas method. Procedia Engineering, 121, 662666. https://doi.org/10.1016/j.proeng.2015.08.1061

Zhang, Z., Zhao, Y., Zhou, M., Tao, P., \& Li, R. (2017). Measurement of indoor air quality in Chinese charcoal barbecue restaurants. Procedia Engineering, 205, 887-894. https://doi.org/10.1016/j.proeng.2017.10.088
Zhao, K., Zhou, X., \& Zhao, B. (2010). Cooking generated particles' impact on indoor air quality of university cafeteria. Building Simulation, 3(1), 10. https://doi.org/ 10.1007/s12273-010-0305-8

Zoellick, B., Nelson, S. J., \& Schauffler, M. (2012). Participatory science and education: Bringing both views into focus. Frontiers in Ecology and the Environment, 10(6), 310-313. https://doi.org/10.1890/110277 


\section{APPENDIX A}

Reference values from reference literature, or literature some extent comparable to the respective scenario

\begin{tabular}{|c|c|c|c|}
\hline & $\begin{array}{l}\text { Reference values } \\
\mathbf{R}_{\text {Avg }}\left(\mathbf{R}_{\text {std }}\right)\left[\mathbf{R}_{\text {Min }}-\mathbf{R}_{\text {Max }}\right]\end{array}$ & Reference study & Remark \\
\hline \multicolumn{4}{|c|}{ Restaurants (1A visitors PPM CO; 1B kitchen PPM CO; 1C outside kitchen PPM CO) } \\
\hline $1 \mathrm{~A}$ & $12.3[2.6-22.5]$ & (Zhang et al., 2017) & \multirow{2}{*}{$\begin{array}{l}\text { Kitchens with mixed gas and charcoal (barbecue) appliances; } \\
\text { higher values in dedicated biomass fuel kitchens might not be } \\
\text { invalid. }\end{array}$} \\
\hline 1B & $21.1[3.2-42.6]$ & (Zhang et al., 2017) & \\
\hline $1 \mathrm{C}$ & $0.2(2.97)[0-20]$ & (Leavey et al., 2015) & $\begin{array}{l}\text { Reference study is not outside restaurant kitchens, but outside } \\
\text { household kitchens. Mean and std are geometric. }\end{array}$ \\
\hline \multicolumn{4}{|c|}{ Households (2A kitchen biomass PPM CO; 2B kitchen electrified PPM CO; 2C coffee ceremony inside $\mu \mathrm{g} / \mathrm{m}^{3}$ PM2.5) } \\
\hline $2 \mathrm{~A}$ & $\begin{array}{l}7.9(11.2)^{\mathrm{y}}[0.1-54] \\
7.8(15.1)^{\mathrm{y}} \\
22.3[1.3-146.4] \\
7.5(5.75)^{\mathrm{y}} \\
11.4(15.1)^{\mathrm{y}}[0.1-146]\end{array}$ & $\begin{array}{l}\text { (Clark et al., 2010) } \\
\text { (Khalequzzaman et al., 2011) } \\
\text { (Leavey et al., 2015) } \\
\text { (Mukhopadhyay et al., 2012) } \\
\text { Values used }\end{array}$ & \\
\hline 2B & $3.9(5.1)^{\mathrm{y}}$ & $\begin{array}{l}\text { (Barron \& Torero, 2017; Rollin et al., } \\
\text { 2004) }\end{array}$ & $\begin{array}{l}50-66 \% \text { reduction in electrified vs unelectrified kitchens. Values } \\
\text { based on } 2 \mathrm{~A}^{*} 0.34 \text {. }\end{array}$ \\
\hline $2 \mathrm{C}$ & $1373.5(870)^{\mathrm{y}}[<720-4200]$ & (Keil et al., 2010) & $\begin{array}{l}\text { Reference values are in PM4, and lower limit of measurement } \\
\text { method is } 720 \mu \mathrm{g} / \mathrm{m}^{3} \text {. Lower student values of PM2.5 might not } \\
\text { be invalid. }\end{array}$ \\
\hline \multicolumn{4}{|c|}{ Waste burning (3B $\mu \mathrm{g} / \mathrm{m}^{3}$ PM2.5) } \\
\hline 3B & {$[622-1110]$} & (Sive & $\begin{array}{l}\text { Reported values not based on measurements, but on modelled } \\
\text { PM10 values and the ratio between reported PM2.5 and PM10 } \\
\text { emission values. }\end{array}$ \\
\hline \multicolumn{4}{|c|}{$\begin{array}{l}\text { Ambient (4A Bus station PPM CO; 4B Busstation } \mu \mathrm{g} / \mathrm{m}^{3} \text { PM2.5; 4C Outside bus station } / \mathrm{roadside} \mu \mathrm{g} / \mathrm{m}^{3} \text { PM2.5; 4D Generator } \mu \mathrm{g} / \mathrm{m}^{3} \\
\text { PM2.5; 4E Smoking } \mu \mathrm{g} / \mathrm{m}^{3} \text { PM2.5) }\end{array}$} \\
\hline $4 \mathrm{~A}$ & $8.5(1.5)^{\mathrm{y}}[6.5-9.8]$ & (Salama et al., 2017) & Values from Salama based on the 'parking' measurements. \\
\hline 4B & $\begin{array}{l}163(28)[121-223] \\
127[78.5-182] \\
55.2[49-75] \\
115(28)[49-223] \\
\end{array}$ & $\begin{array}{l}\text { (Y.-H. Cheng et al., 2011) } \\
\text { (Razif \& Abib, 2006) } \\
\text { (Salama et al., 2017) } \\
\text { Values used }\end{array}$ & $\begin{array}{l}\text { Values from Salama based on the 'parking' measurements. } \\
\text { PM10 values from (Razif \& Abib, 2006) changed to PM2.5 based } \\
\text { on ratio } 0.49 \text { from (Y.-H. Cheng et al., 2011; Salama et al., 2017) }\end{array}$ \\
\hline $4 \mathrm{C}$ & {$[7.6-55.8]$} & (Jamriska et al., 2005) & $\begin{array}{l}\text { oncentration 1:4-1:10. } \\
\text { /4 }\end{array}$ \\
\hline 4D & $\begin{array}{l}374(75.6)^{\mathrm{y}}[221-492] \\
83(54.2)^{\mathrm{y}}[26-309] \\
85.9[7.9-173] \\
181(75.6)^{\mathrm{y}}[7.9-492]\end{array}$ & $\begin{array}{l}\text { (Giwa, Nwaokocha, \& Adeyemi, } \\
\text { 2019) } \\
\text { (Giwa, Nwaokocha, \& Samuel, 2019) } \\
\text { (Oguntoke \& Adeyemi, 2017) } \\
\text { Values used }\end{array}$ & $\begin{array}{l}\text { Generators in (Oguntoke \& Adeyemi, 2017) are }<25 \mathrm{kVA} \text { and in } \\
\text { (Giwa, Nwaokocha, \& Samuel, 2019) gasoline and }<7.2 \mathrm{kVA} \text {. } \\
\text { Generators in (Giwa, Nwaokocha, \& Adeyemi, 2019) are up to } \\
500 \mathrm{kVA} \text { and diesel, however the mentioned instrument's upper } \\
\text { limit is } 500 \mu \mathrm{g} / \mathrm{m}^{3} \text {. Higher values of PM2.5 might not be invalid }{ }^{\mathrm{a}} \text {. }\end{array}$ \\
\hline & & (Bric & \multirow{6}{*}{$\begin{array}{l}\text { EXPLANATORY NOTES. For multiple studies, the average RAvg } \\
\text { - is based on equally weighed averages. As Rstd the highest } \\
\text { reported SD in any of the reference studies is used. Some } \\
\text { - studies report Stds based on the fluctuation within a } \\
\text { - measurement, while others report SDs based on the variation } \\
\text { - over different measurements (marked withy }{ }^{y} \text {. For } R_{\text {Min }} \text { and } R_{\text {Max }} \\
\text { the lowest and highest value (over different measurements) are } \\
\text { used. }\end{array}$} \\
\hline $4 \mathrm{E}$ & $\begin{array}{l}131(213)^{\mathrm{y}}[9.7-887] \\
127.1(213)^{\mathrm{y}}[9.7-887]\end{array}$ & $\begin{array}{l}\text { (Williams Jr e } \\
\text { Values used }\end{array}$ & \\
\hline & $\begin{array}{l}\text { ation (5B Dormitory PP } \\
\text { arant PPM CO} \\
\text { ) }\end{array}$ & 5D Classroom PPM CO$~_{2} ; 5 \mathrm{E}$ & \\
\hline 5B & $1416[650-2900]$ & (Jenkins, 2018) & \\
\hline 5D & $1351(341)[478-4093]$ & (Soomro et al., 2019) & \\
\hline $5 \mathrm{E}$ & $\begin{array}{l}1234(495)[618-1835] \\
623[400-890] \\
929(495)[400-1835]\end{array}$ & $\begin{array}{l}\text { (Akbar-Khanzadeh et al., 2002) } \\
\text { (Zhang et al., 2017) } \\
\text { Values used }\end{array}$ & \\
\hline
\end{tabular}

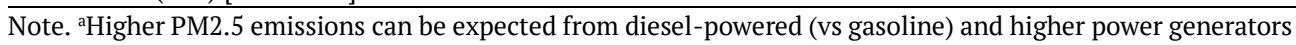

